Research Article

\title{
Comparison of 304 SS, 2205 SS, and 410 SS Corrosion by Sulfate-Reducing Desulfovibrio ferrophilus
}

\author{
Junlei Wang (D), ${ }^{1,2}$ Hongfang Liu $\left(\mathbb{D},{ }^{2}\right.$ Pruch Kijkla, ${ }^{1}$ Sith Kumseranee, ${ }^{3}$ Suchada Punpruk, ${ }^{3}$ \\ Magdy El-Said Mohamed, ${ }^{4}$ Mazen A. Saleh, ${ }^{4}$ and Tingyue Gu $\mathbb{D D}^{1}$ \\ ${ }^{1}$ Department of Chemical and Biomolecular Engineering, Institute for Corrosion and Multiphase Technology, \\ Ohio University, Athens, OH 45701, USA \\ ${ }^{2}$ School of Chemistry and Chemical Engineering, Huazhong University of Science and Technology, Wuhan, Hubei 430074, China \\ ${ }^{3}$ PTT Exploration and Production, Bangkok 10900, Thailand \\ ${ }^{4}$ Research and Development Center, Saudi Arabian Oil Company, Dhahran 31311, Saudi Arabia
}

Correspondence should be addressed to Hongfang Liu; liuhf@hust.edu.cn and Tingyue Gu; gu@ohio.edu

Received 24 May 2021; Accepted 31 May 2021; Published 17 June 2021

Academic Editor: Liviu Mitu

Copyright ( 92021 Junlei Wang et al. This is an open access article distributed under the Creative Commons Attribution License, which permits unrestricted use, distribution, and reproduction in any medium, provided the original work is properly cited.

\begin{abstract}
Three types of stainless steel (304 SS, 410 SS, and 2205 SS) were evaluated for their corrosion behaviors in microbiologically influenced corrosion (MIC) by Desulfovibrio ferrophilus strain IS5, a relatively new and very corrosive sulfate-reducing bacteria (SRB) strain. The incubation lasted for 7 days in enriched artificial seawater at $28^{\circ} \mathrm{C}$ and the results showed that $410 \mathrm{SS}$ had a rather large weight loss $\left(6.2 \mathrm{mg} / \mathrm{cm}^{2}\right)$ and a maximum pit depth $(118 \mu \mathrm{m})$, but $2205 \mathrm{SS}$ and $304 \mathrm{SS}$ did not suffer from significant weight loss or pitting. Electrochemical tests indicated that 2205 SS was slightly more resistant to SRB MIC than 304 SS, while 410 SS was far less resistant.
\end{abstract}

\section{Introduction}

Stainless steel is widely used in various industries. The typical austenitic stainless steel such as 304 SS is widely used in pipelines and power plants because of its good ductility, wear resistance, and corrosion resistance $[1,2]$. Classic martensitic stainless 410 series have been widely used in petroleum production and machine parts, exhibiting high strength and hardness but being less resistant to corrosion compared to other types of stainless steel [3]. For instance, 410 SS is the most popular martensitic grade SS. 2205 SS is duplex stainless steel with a mixture of austenitic and delta-ferritic phases [4]. It is widely used in heat exchanger pipes, pressure vessels, and marine engineering [5, 6]. Duplex stainless steel has demonstrated that its corrosion resistance in these media is similar to that of traditional austenitic types or even better [7].

Microbiologically influenced corrosion (MIC) is one of the main causes of metal corrosion $[8,9]$. Twenty percent of corrosion costs is attributed to MIC, leading to a great economic loss every year based on reports [10]. MIC is widespread in the oil and gas industry, marine systems, and water cooling systems, involving different kinds of bacteria. Various microorganisms such as bacteria including sulfatereducing bacteria (SRB) and acid-producing bacteria (APB), iron-oxidizing bacteria (IOB), nitrate-reducing bacteria (NRB), fungi, and methanogens (archaea) have been reported to lead to serious corrosion by their metabolic activities in different environments [11-17].

Among them, SRB are the main culprits in MIC because sulfate is widely distributed in soil, seawater, and oil and gas systems $[12,18-20]$. They can utilize sulfate as the terminal electron acceptor and organic carbon as electron donor $[21,22]$. Dinh et al. isolated a specialized and novel SRB strain with a much higher corrosion ability known as Desulfovibrio ferrophilus strain IS5. It can utilize elemental iron as the sole and direct electron donor for its metabolism [23]. D. ferrophilus reduces sulfate using Fe as an electron donor much faster than traditional hydrogen consumption SRB species [23]. It is interesting to investigate its corrosion against various stainless steel.

In this work, three types of stainless steel (304 SS, 2205 SS, and 410 SS) were tested for their resistance against MIC 
by $D$. ferrophilus incubated in enriched artificial seawater. Planktonic and sessile cell counts were used to describe microbial growth. Weight loss and pit depth were used to quantify corrosion severity. Electrochemical measurements were used to corroborate weight loss and pitting data trends and to provide transient corrosion behavior.

\section{Materials and Methods}

2.1. Specimen Preparation. The elemental compositions of the 3 stainless steel types are listed in Table 1. Stainless steel coupons with a $1 \mathrm{~cm} \times 1 \mathrm{~cm}$ unpainted top area were used for corrosion testing. Before testing, coupons were abraded by 180-, 400-, and 600-grit emery papers sequentially, then cleaned with 100\% isopropanol, and sterilized under an UV lamp for $30 \mathrm{~min}$ [24]. After 7 days of incubation, coupons were taken out. Corrosion products and the biofilm on each coupon surface were removed using Clarke's solution [25]. The cleaned coupons were weighed using an analytical balance with a readability of $0.1 \mathrm{mg}$. The coupon surfaces were scanned using an infinite focus microscope (IFM) (Model ALC13, Alicona Imaging GmbH, Graz, Austria) to analyze pitting corrosion. An optical microscope at 400x was used to visualize pits on coupons.

2.2. Culture Medium Preparation. D. ferrophilus strain IS5 was purchased from a culture collection (DSMZ, Braunschweig, Germany). It was incubated at $28^{\circ} \mathrm{C}$ in enriched artificial seawater (EASW) for 7 days. The chemical composition of EASW was as follows (in $\mathrm{g} / \mathrm{L}$ ): $\mathrm{NaCl} 23.476$, $\mathrm{Na}_{2} \mathrm{SO}_{4}$ 3.917, $\mathrm{NaHCO}_{3}$ 0.192, KCl 0.664, KBr 0.096, $\mathrm{SrCl}_{2} \cdot 6 \mathrm{H}_{2} \mathrm{O} \quad 0.04, \mathrm{H}_{3} \mathrm{BO}_{3} 0.026$, trisodium citrate 0.5 , $\mathrm{CaCl}_{2} \cdot 2 \mathrm{H}_{2} \mathrm{O} 1.469, \mathrm{MgCl}_{2} \cdot 6 \mathrm{H}_{2} \mathrm{O} 10.61$, yeast extract 1 , sodium lactate 3.5, $\mathrm{NH}_{4} \mathrm{Cl} 0.1, \mathrm{CaSO}_{4} \cdot 2 \mathrm{H}_{2} \mathrm{O} 0.1, \mathrm{Fe}\left(\mathrm{NH}_{4}\right)_{2}$ $\left(\mathrm{SO}_{4}\right)_{2} \cdot 6 \mathrm{H}_{2} \mathrm{O}$ 1.38, and $\mathrm{K}_{2} \mathrm{HPO}_{4}$ 0.05. Its initial $\mathrm{pH}$ was adjusted to 7.0-7.2 using a $1 \mathrm{M}(\mathrm{w} / \mathrm{w}) \mathrm{NaOH}$ solution before sterilization. The culture medium and tools were sterilized in an autoclave (Model MLS-3751L, Panasonic, Osaka, Japan) for $20 \mathrm{~min}$ at $121^{\circ} \mathrm{C}$. Then, the EASW was sparged with 99.99\% (v/v) $\mathrm{N}_{2}$ for $1 \mathrm{~h}$ to remove $\mathrm{O}_{2}$ [26]. A L-cysteine stock solution was sterilized using a $0.22 \mu \mathrm{m}$ sterile filter (Stericup, Millipore, Bedford, MA, USA). It was added to the culture medium to reach $100 \mathrm{ppm}(\mathrm{w} / \mathrm{w})$ as an oxygen scavenger.

All anaerobic manipulations were conducted in an anaerobic chamber (Model HE-493, Vacuum Atmosphere Company, Hawthorne, CA, USA) with $\mathrm{N}_{2}$ atmosphere [27]. All chemicals in this work were purchased from either Sigma-Aldrich (St. Louis, MO, USA) or Fisher Scientific (Pittsburgh, PA, USA).

2.3. Planktonic and Sessile Cell Counts. Each $125 \mathrm{~mL}$ vial contained 3 coupons in $100 \mathrm{~mL}$ EASW plus $1 \mathrm{~mL}$ inoculum with roughly $23 \mathrm{~mL}$ headspace. After the 7-day incubation at $28^{\circ} \mathrm{C}$, coupons were taken out and rinsed in a $\mathrm{pH} 7.4$ phosphate-buffered solution (PBS) 3 times to remove loosely attached planktonic cells and culture medium. Sessile cells on a coupon were removed using a small disposable brush into a $10 \mathrm{~mL}$ PBS solution in a disposable plastic weighing dish. Then, the brush, the coupon, and $10 \mathrm{~mL}$ PBS solution were vortexed together in a $50 \mathrm{~mL}$ conical tube for $30 \mathrm{~s}$. For planktonic cell counting, $1 \mathrm{~mL}$ broth from a $125 \mathrm{~mL}$ anaerobic vial was first diluted with $9 \mathrm{~mL}$ PBS buffer in a $50 \mathrm{~mL}$ conical tube. Then, this tube was vortexed for $30 \mathrm{~s}$ before the diluted cell suspension was counted using a hemocytometer. In this work, a hemocytometer was used to measure planktonic and sessile cell count liquid suspensions under an optical microscope at 400x magnification. This method is far more accurate than MPN (most probably number) method to enumerate planktonic and sessile cell counts if individual cells can be seen.

2.4. Electrochemical Measurements. A three-electrode electrochemical glass cell setup (Figure 1) was used for electrochemical measurements. Each glass cell was filled with $100 \mathrm{~mL}$ EASW with a headspace of $25 \mathrm{~mL}$. A stainless steel coupon sealed in epoxy with an exposed area of $1^{\circ} \mathrm{cm}^{2}$ served as the working electrode. Platinum sheet and saturated calomel electrode (SCE) served as counter and reference electrode, respectively [28]. During the 7-day D. ferrophilus incubation, open circuit potential (OCP), linear polarization resistance (LPR), and electrochemical impedance spectroscopy (EIS) were measured daily. Potentiodynamic polarization (PDP) was performed at the end of 7 th day. All electrochemical tests were conducted using a VersaSTAT 3 potentiostat (Princeton Applied Research, Oak Ridge, TN, USA). When OCP became stable, LPR were measured from $-10 \mathrm{mV}$ to $10 \mathrm{mV}$ (vs. OCP) with a scanning rate of $0.167 \mathrm{mV} / \mathrm{s}$ [29]. EIS were conducted from $105 \mathrm{~Hz}$ to $0.01 \mathrm{~Hz}$ with a $10 \mathrm{mV}$ AC amplitude $[12,30,31]$. PDP was measured at the end of incubation. To scan from OCP to $200 \mathrm{mV}$ one working electrode was used, and from OCP to $-200 \mathrm{mV}$, another working electrode was used in a different glass cell [11]. EIS was analyzed using Zview software (version 2). LPR and PDP were analyzed using Cview software (version 2).

\section{Results and Discussion}

3.1. Cell Counts and Weight Loss. Figure 1(a) shows an electrochemical glass cell right after inoculation (day 0 ). The broth darkened after the 7-day incubation (Figure 1(b)) due to FeS precipitation, which proves that D. ferrophilus grew well and produced a lot of FeS.

Table 2 shows the planktonic and sessile cells after the 7day incubation at $28^{\circ} \mathrm{C}$. Obviously, $410 \mathrm{SS}$ vial had the largest numbers of both planktonic and sessile cells, but much smaller than one log. The largest sessile cell count in the 410 SS vial was a factor for why 410 SS had the largest corrosion rate $\left(6.2 \mathrm{mg} / \mathrm{cm}^{2}\right)$ in Table 3. SRB MIC of SS belongs to EETMIC (extracellular electron transfer MIC) [21, 32]. More sessile cells on the metal surface could take more electrons from the metal, which led to more serious 410 SS corrosion. More importantly, 410 SS has much less Cr and Ni than 304 SS and 2205 SS (Table 1). It is known to be less resistant to abiotic corrosion compared to the other two types of stainless steel [3]. In comparison, 304 SS and 2205 SS had no detectable weight loss. 
TABLe 1: Elemental compositions (wt. \%) of 3 stainless steel types (Fe balance).

\begin{tabular}{|c|c|c|c|c|c|c|c|c|c|c|c|c|c|}
\hline SS & $\mathrm{C}$ & $\mathrm{P}$ & $S$ & $\mathrm{Si}$ & $\mathrm{Mn}$ & $\mathrm{Cr}$ & $\mathrm{Ni}$ & Mo & $\mathrm{N}$ & $\mathrm{Cu}$ & $\mathrm{Co}$ & $\mathrm{Al}$ & Sn \\
\hline 304 & 0.063 & 0.031 & 0.002 & 0.312 & 1.422 & 18.330 & 8.118 & 0.297 & 0.045 & 0.316 & & & \\
\hline 410 & 0.129 & 0.02 & 0.001 & 0.29 & 0.43 & 12.24 & 0.42 & 0.12 & 0.027 & 0.05 & 0.12 & 0.02 & 0.001 \\
\hline 2205 & 0.029 & 0.029 & 0.001 & 0.387 & 1.721 & 22.491 & 4.721 & 3.221 & 0.174 & 0.237 & & & \\
\hline
\end{tabular}

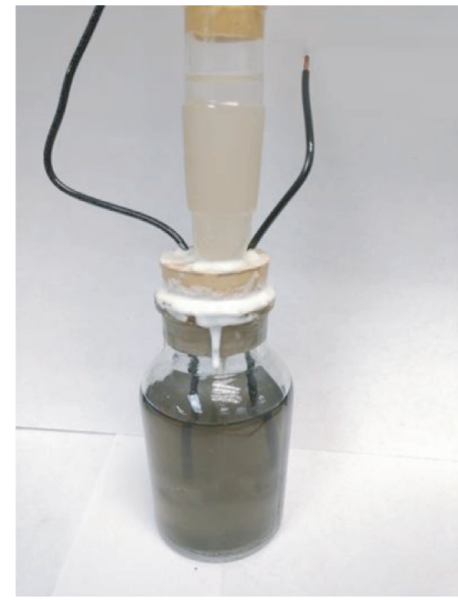

(a)

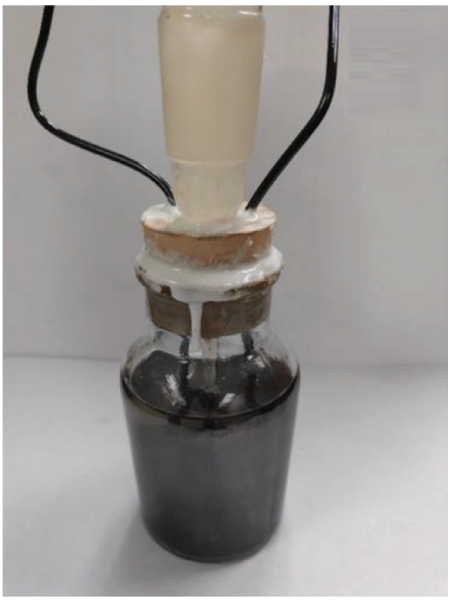

(b)

Figure 1: Three-electrode electrochemical glass cells at day 0 (a) and at the end of 7-day incubation (b). Note: the left wire was for the counterelectrode and the right wire for the working electrode. The center glass tube was for the reference electrode.

TABLE 2: SRB cell counts after 7-day incubation.

\begin{tabular}{lcc}
\hline Metal & Planktonic $\left(\times 10^{6}\right.$ cells $\left./ \mathrm{ml}\right)$ & Sessile $\left(\times 10^{7}\right.$ cells $\left./ \mathrm{cm}^{2}\right)$ \\
\hline 304 SS & $1.5 \pm 0.1$ & $1.7 \pm 0.2$ \\
410 SS & $2.5 \pm 0.4$ & $6.3 \pm 0.3$ \\
2205 SS & $1.8 \pm 0.2$ & $3.5 \pm 0.3$ \\
\hline
\end{tabular}

TABLE 3: Weight loss after 7-day incubation (standard deviations from replicate coupons in three SRB bottles).

\begin{tabular}{lr}
\hline Metal & Weight loss $\left(\mathrm{mg} / \mathrm{cm}^{2}\right)$ \\
\hline 304 SS & Undetectable \\
410 SS & $6.2 \pm 0.2$ \\
2205 SS & Undetectable \\
\hline
\end{tabular}

3.2. $p H$ Values. The $\mathrm{pH}$ values before and after the 7-day incubation are listed in Table 4. $\mathrm{pH}$ was affected by SRB metabolism and corrosion. In the typical SRB metabolism, lactate oxidation in Reaction (1) coupled with sulfate reduction in Reaction (3) does not produce acidity [22]. On the other hand, lactate oxidation produces $\mathrm{CO}_{2}$ which can cause some acidity. The escape of $\mathrm{H}_{2} \mathrm{~S}$ to the headspace actually takes away some protons from the culture medium, leading to a slight increase in broth $\mathrm{pH}$ [22]. More important, was the fact that iron oxidation in Reaction (2) coupled with sulfate reduction in Reaction (3) consumes protons. The 410 SS vials had much more weight loss, contributing to $\mathrm{pH}$ increase. Thus, in MIC studies, a shift in $\mathrm{pH}$ sometimes can be a predictor of weight loss change:

$$
\begin{gathered}
2 \mathrm{CH}_{3} \mathrm{CHOHCOO}^{-}+2 \mathrm{H}_{2} \mathrm{O} \longrightarrow 2 \mathrm{CH}_{3} \mathrm{COO}^{-}+2 \mathrm{CO}_{2}+8 \mathrm{H}^{+}+8 \mathrm{e}^{-} \\
4 \mathrm{Fe} \longrightarrow 4 \mathrm{Fe}^{2+}+8 \mathrm{e}^{-} \\
\mathrm{SO}_{4}^{2-}+9 \mathrm{H}^{+}+8 \mathrm{e}^{-} \longrightarrow \mathrm{HS}^{-}+4 \mathrm{H}_{2} \mathrm{O}
\end{gathered}
$$


TABLE 4: Broth $\mathrm{pH}$ before and after incubation in $125 \mathrm{~mL}$ vial.

\begin{tabular}{lcc}
\hline Metal & Day 0 & Day 7 \\
\hline 304 SS & 7.01 & 6.75 \\
410 SS & 7.01 & 7.13 \\
2205 SS & 7.01 & 6.79 \\
\hline
\end{tabular}

Table 2 shows the highest planktonic and sessile cell counts occurred for the vial with 410 SS among the 3 cases. More $\mathrm{H}_{2} \mathrm{~S}$ was likely produced due to better growth.

Some researchers blame $\mathrm{H}_{2} \mathrm{~S}$ as behind SRB MIC of $\mathrm{Fe}(0)$ based on the following reaction [33]:

$$
\mathrm{Fe}+\mathrm{H}_{2} \mathrm{~S} \longrightarrow \mathrm{FeS}+\mathrm{H}_{2} \text {. }
$$

However, $\mathrm{H}_{2} \mathrm{~S}$ corrosion of carbon steel requires a significantly acidic $\mathrm{pH}$ as demonstrated in abiotic $\mathrm{H}_{2} \mathrm{~S}$ corrosion research [34]. A telltale sign for $\mathrm{H}_{2} \mathrm{~S}$ corrosion is hydrogen evolution, which is a very sensitive indicator in a sealed vial. It was found that, for an SRB culture, the hydrogen gas concentration profiles in the headspaces of sealed anaerobic vials were the same with and without carbon steel coupons [24]. Thus, the corrosion process did not generate hydrogen gas. This effectively ruled out $\mathrm{H}_{2} \mathrm{~S}$ corrosion as a contributor to SRB MIC of carbon steel near neutral $\mathrm{pH}$. It was sessile cells' harvest of energy from elemental iron via extracellular electron transfer (EET) that is behind the MIC. Thus, this type of MIC is known as EET-MIC [21, 24, 32].

3.3. IFM. After removing corrosion products and biofilms upon ending the 7-day incubation, the surface morphologies of the stainless steel were examined with results shown in Figure 2. In Figure 2, 304 SS and 2205 SS show a smooth surface with polishing lines. However, 410 SS shows serious localized corrosion in Figure 2(b). Figure 3 shows coupon surface IFM profiles support this observation, showing a large maximum pit depth of $118 \mu \mathrm{m}$ for 410 SS, while it was hard to identify welldefined pits in the IFM profiles for 304 SS and 2205 SS surfaces. It was also hard to notice any corrosion pits under a light microscope at $400 \times$ in Figure 2. Figure 2 shows that $118 \mu \mathrm{m}$ pit on 410 SS has a surface diameter of $1 \mathrm{~mm}$. Assuming that the pit had a cylinder shape, the weight loss for the cylinder alone would be $0.72 \mathrm{mg}$ based on 410 SS density of $7.74 \mathrm{~g} / \mathrm{cm}^{3}$. This large pit was easily visible even to the naked eye. Although in the literature a weight loss as high as $5.7 \mathrm{mg} / \mathrm{cm}^{2}$, which is close to that for $410 \mathrm{SS}$ in this work, has been reported for carbon steel MIC by a pure-strain SRB in 7 days [35], the $118 \mu \mathrm{m}$ pit depth obtained in this work for 410 SS is easily a record in pit depth for any pure-strain SRB MIC of stainless steel with strict $\mathrm{O}_{2}$ control, suggesting a superior ability of $D$. ferrophilus for pitting corrosion. It should be noted that severe 410 SS pitting had a random nature in short-term tests using small $\left(1 \mathrm{~cm}^{2}\right)$ coupon surface areas. Some replicate 410 SS coupons did not have obvious pits. In this work, they were excluded.

3.4. EIS. EIS measurements were performed daily. Nyquist plots of the 3 stainless steel types during the 7 days of incubation are shown in Figure 4. The corresponding fitted parameters are listed in Table 5 for the equivalent circuit models shown in Figure 5. Figure 5(b) is used to fit days 3, 5, and 7 in Figure 4(c). All other EIS curves were fitted using Figure 5(a). On day 0 in Figure 4(a), the diameter of the semicircle of 410 SS is the largest and that of 304 SS is the smallest. This means before biofilms were established on the coupon surfaces, 410 SS and 2205 SS were more corrosion resistant than 304 SS. As SRB started to grow, the diameters decreased sharply for all the 3 stainless steel types. Charge transfer resistance $\left(R_{\mathrm{ct}}\right)$ decreased by 102 (Table 5), indicating SRB metabolic activities had a large effect on stainless steel corrosion. Among the 3 stainless steel types, 304 SS (Figure 4(b)) and 2205 SS (Figure 4(d)) had much larger corrosion resistance (in terms of $R_{f}+R_{\mathrm{ct}}$ ) from day 1 to day 7, indicating that 304 SS was more stable in the SRB environment than 410 SS (Figure 4(c)). The sessile cell count on 410 SS was only 3.7 times larger than 304 SS. However, it was corroded much more than the sessile cell increase could explain. Thus, the alloying components in 410 SS played a big role. Table 1 shows that it has much less $\mathrm{Cr}$ and Ni than 304 SS and 2205 SS. The diffusion process after day 3 indicated by 410 SS was attributed to the build-up of corrosion products, which required a Warburg impedance element in Figure 5(b) to deal with the mass transfer resistance.

3.5. OCP. Figure 6 shows the OCP tendency with time. OCP of the 3 stainless steel types fluctuated in the first 2 days and then kept relatively stable. The large fluctuation in the first 2 days could be attributed to the SRB cell attachment. After 3 days of incubation, the 410 SS OCP curve is much lower than those for 304 SS and 2205 SS, indicating much higher thermodynamic tendency for 410 SS corrosion. This is consistent with the weight loss data in Table 3.

3.6. Linear Polarization Resistance. Figure 7 shows the $R_{p}$ tendency with time. $R_{p}$ is inversely proportional to corrosion rate. On day 0,410 SS had the highest $R_{p}$ before biofilm establishment. After 1 day of incubation, Figure 7 indicates that the 410 SS $R_{p}$ curve is much higher than those of 304 SS and 2205 SS after the first-day transient period, supporting the weight loss data once again.

3.7. Potentiodynamic Polarization. Figure 8 shows the potentiodynamic polarization curves of the 3 stainless steel types performed after 7 days of incubation. It is obvious to see that 410 SS was corroded much more severely than the other two stainless steel types. Both the cathode and anode curves shift to the right, leading to a much larger corrosion current density $\left(i_{\text {corr }}\right)$. The fitted Tafel parameters are listed 

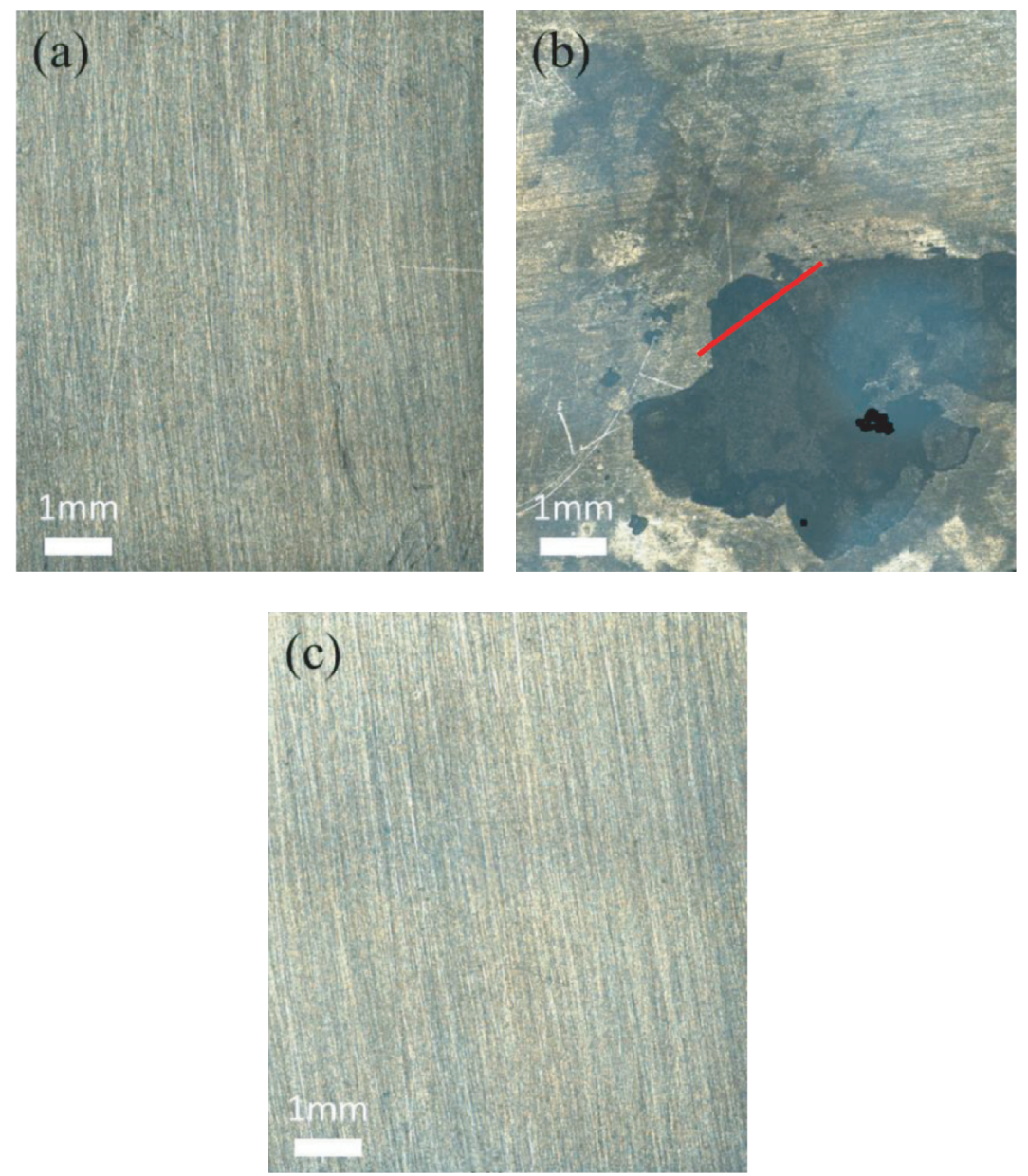

FIGURE 2: Surface images of 3 stainless steel types after 7-day incubation: (a) 304 SS, (b) 410 SS, and (c) 2205 SS. Note: red bar indicates IFM scan path in Figure 3(b).

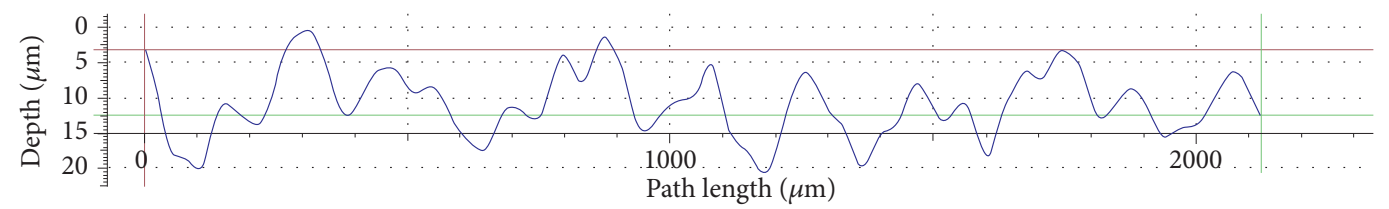

(a)

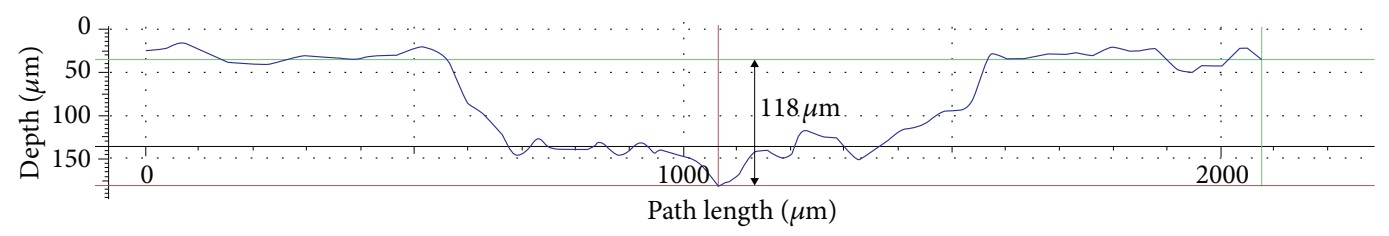

(b)

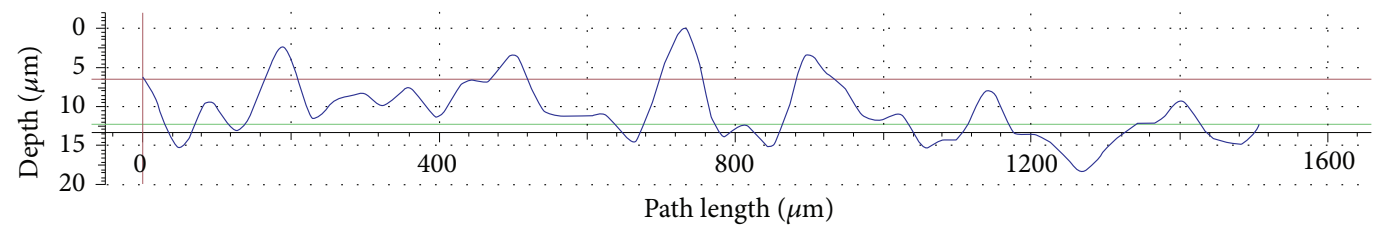

(c)

Figure 3: Surface profiles of three kinds of stainless steel after 7-day incubation: (a) 304 SS, (b) 410 SS, and (c) 2205 SS. 

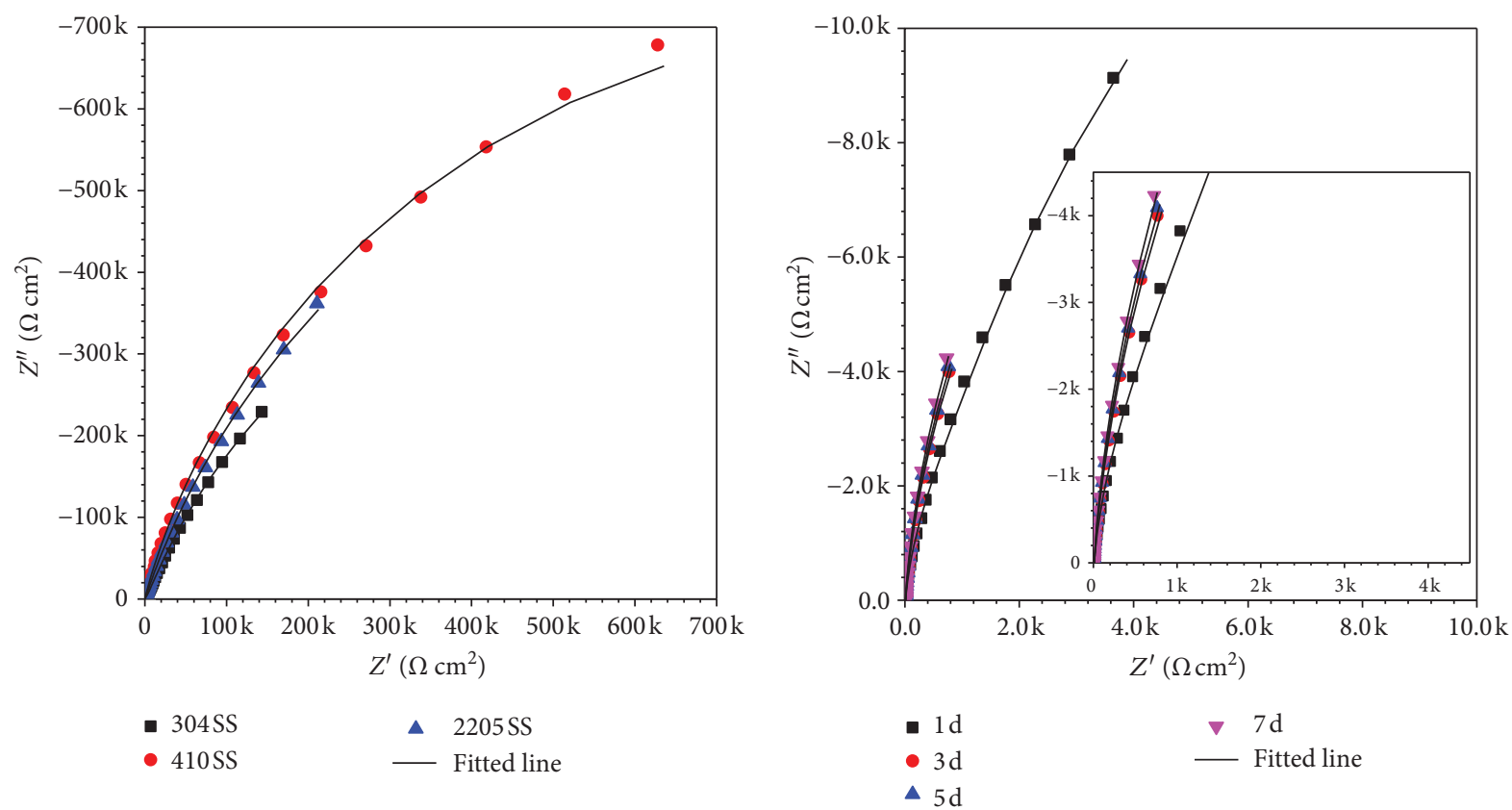

(a)

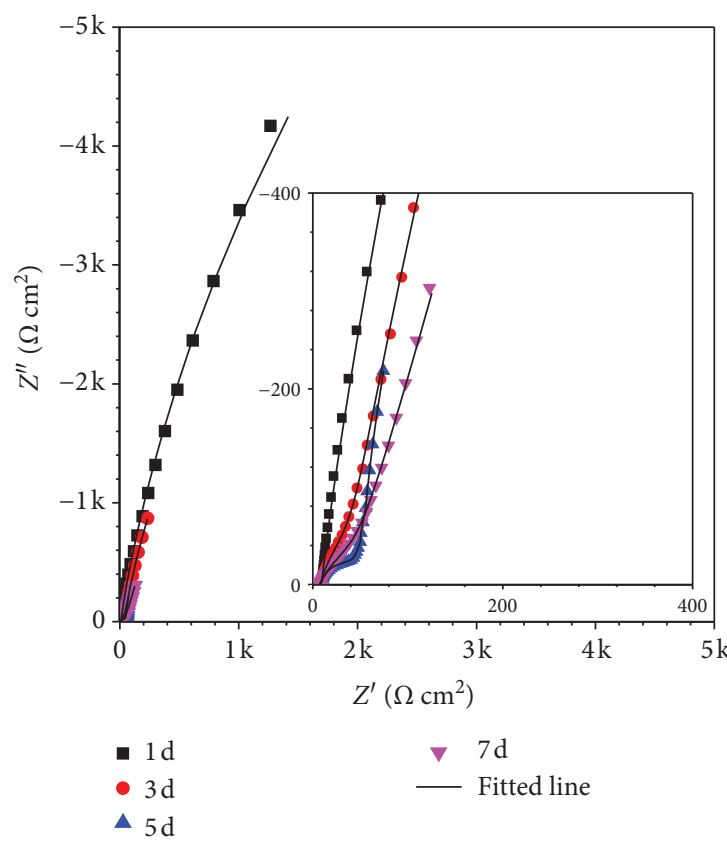

(c)

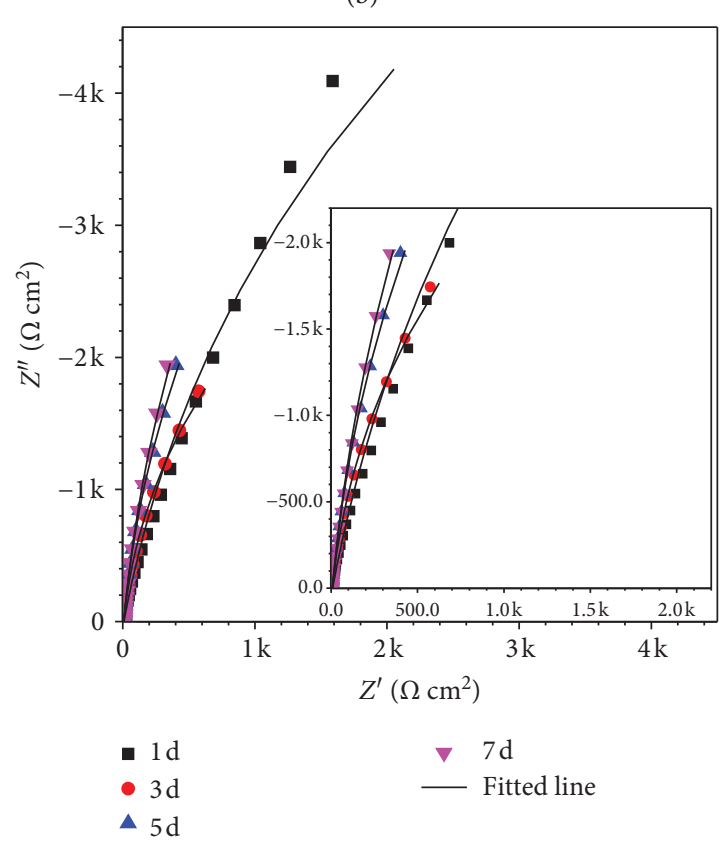

(d)

FIGURE 4: Nyquist plots of three stainless steel types during 7-day incubation. (a) 0 day. (b) 304 SS. (c) 410 SS. (d) 2205 SS.

TABLE 5: Fitted electrochemical parameters from EIS data.

\begin{tabular}{|c|c|c|c|c|c|c|c|c|c|c|}
\hline Day & $R_{\mathrm{s}}\left(\Omega \mathrm{cm}^{2}\right)$ & $Q_{\mathrm{f}}\left(\Omega^{-1} \mathrm{~s}^{\mathrm{n}} \mathrm{cm}^{-2}\right)$ & $n_{1}$ & $R_{\mathrm{f}}\left(\Omega \mathrm{cm}^{2}\right)$ & $\begin{array}{c}Q_{\mathrm{dl}}\left(\Omega^{-1} \mathrm{~s}^{\mathrm{n}}\right. \\
\left.\mathrm{cm}^{-2}\right)\end{array}$ & $n_{2}$ & $R_{\mathrm{ct}}\left(\Omega \mathrm{cm}^{2}\right)$ & $W 1-R\left(\Omega \mathrm{cm}^{2}\right)$ & $W 1-T(\mathrm{~s})$ & $W 1-P$ \\
\hline \multicolumn{11}{|l|}{304 SS } \\
\hline 0 & 9.2 & $1.87 \times 10^{-5}$ & 0.77 & $1.60 \times 10^{4}$ & $1.04 \times 10^{-5}$ & 0.76 & $1.34 \times 10^{6}$ & & & \\
\hline 1 & 10.8 & $2.78 \times 10^{-4}$ & 0.95 & 5.46 & $8.08 \times 10^{-4}$ & 0.84 & $4.63 \times 10^{4}$ & & & \\
\hline 3 & 12.1 & $7.80 \times 10^{-4}$ & 0.92 & 4.17 & $2.56 \times 10^{-3}$ & 0.91 & $3.93 \times 10^{4}$ & & & \\
\hline 5 & 10.8 & $9.49 \times 10^{-4}$ & 0.94 & 4.13 & $2.37 \times 10^{-3}$ & 0.90 & $4.31 \times 10^{4}$ & & & \\
\hline 7 & 10.7 & $9.15 \times 10^{-4}$ & 0.92 & 3.63 & $2.33 \times 10^{-3}$ & 0.91 & $4.80 \times 10^{4}$ & & & \\
\hline
\end{tabular}


TABle 5: Continued.

\begin{tabular}{|c|c|c|c|c|c|c|c|c|c|c|}
\hline Day & $R_{\mathrm{s}}\left(\Omega \mathrm{cm}^{2}\right)$ & $Q_{\mathrm{f}}\left(\Omega^{-1} \mathrm{~s}^{\mathrm{n}} \mathrm{cm}^{-2}\right)$ & $n_{1}$ & $R_{\mathrm{f}}\left(\Omega \mathrm{cm}^{2}\right)$ & $\begin{array}{c}Q_{\mathrm{dl}}\left(\Omega^{-1} \mathrm{~s}^{\mathrm{n}}\right. \\
\left.\mathrm{cm}^{-2}\right)\end{array}$ & $n_{2}$ & $R_{\mathrm{ct}}\left(\Omega \mathrm{cm}^{2}\right)$ & $W 1-R\left(\Omega \mathrm{cm}^{2}\right)$ & $W 1-T(\mathrm{~s})$ & $W 1-P$ \\
\hline \multicolumn{11}{|c|}{$410 \mathrm{SS}$} \\
\hline 0 & 8.3 & $1.83 \times 10^{-6}$ & 0.98 & 94 & $6.22 \times 10^{-6}$ & 0.79 & $1.88 \times 10^{6}$ & & & \\
\hline 1 & 8.5 & $2.48 \times 10^{-3}$ & 0.89 & 49 & $1.10 \times 10^{-4}$ & 0.87 & $2.82 \times 10^{4}$ & & & \\
\hline 3 & 7.9 & $7.99 \times 10^{-3}$ & 0.86 & $1.72 \times 10^{2}$ & $4.98 \times 10^{-3}$ & 0.97 & $2.10 \times 10^{3}$ & $9.66 \times 10^{3}$ & 16.7 & 0.61 \\
\hline 5 & 7.9 & $8.45 \times 10^{-3}$ & 0.85 & 52.8 & $4.86 \times 10^{-2}$ & 0.93 & $1.23 \times 10^{2}$ & $2.35 \times 10^{4}$ & 24.8 & 0.82 \\
\hline 7 & 7.8 & $1.15 \times 10^{-2}$ & 0.80 & 70.7 & $1.52 \times 10^{-2}$ & 0.82 & $2.52 \times 10^{2}$ & $3.99 \times 10^{3}$ & 38.5 & 0.73 \\
\hline \multicolumn{11}{|c|}{2205 SS } \\
\hline 0 & 7.7 & $7.45 \times 10^{-6}$ & 0.84 & $4.18 \times 10^{2}$ & $1.23 \times 10^{-5}$ & 0.77 & $1.86 \times 10^{6}$ & & & \\
\hline 1 & 8.3 & $2.26 \times 10^{-3}$ & 0.88 & $1.49 \times 10^{2}$ & $1.79 \times 10^{-12}$ & 0.74 & $1.70 \times 10^{4}$ & & & \\
\hline 3 & 8.1 & $6.84 \times 10^{-3}$ & 0.94 & 64.8 & $3.98 \times 10^{-9}$ & 0.75 & $7.70 \times 10^{3}$ & & & \\
\hline 5 & 7.9 & $6.72 \times 10^{-3}$ & 0.95 & 41.5 & $1.01 \times 10^{-8}$ & 0.71 & $1.57 \times 10^{4}$ & & & \\
\hline 7 & 7.9 & $6.76 \times 10^{-3}$ & 0.94 & 56.0 & $1.09 \times 10^{-8}$ & 0.70 & $2.24 \times 10^{4}$ & & & \\
\hline
\end{tabular}

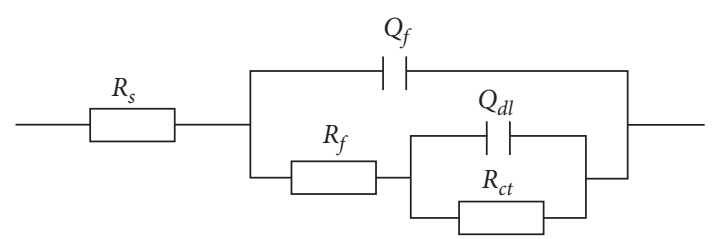

(a)

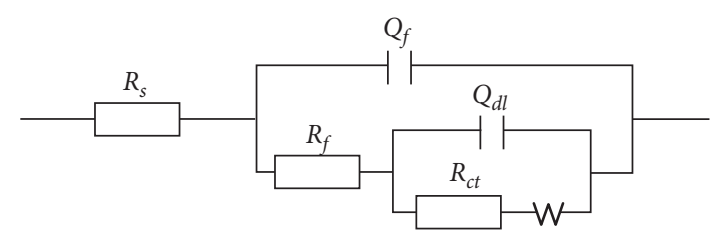

(b)

FIGURE 5: Equivalent circuit model used for fitting EIS data: (a) all conditions, except for (b) 410 SS on days 3-7.

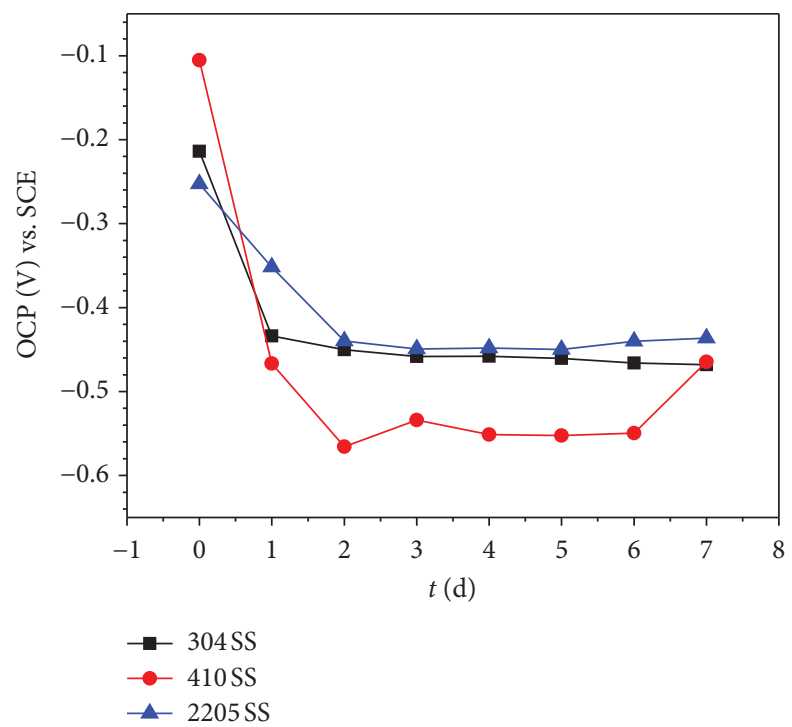

Figure 6: OCP versus time during 7-day incubation. 


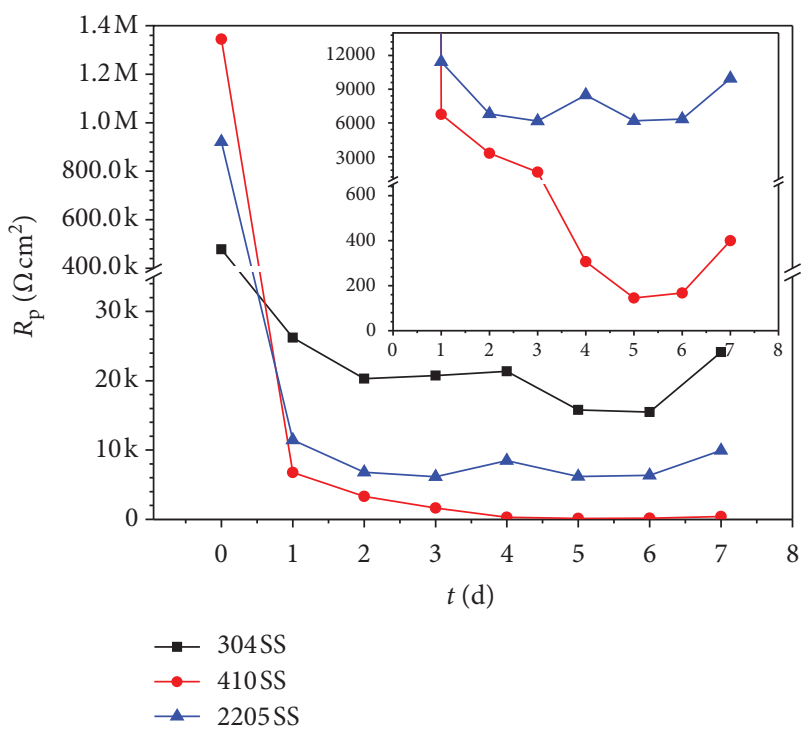

Figure 7: $R_{\mathrm{p}}$ versus time during 7-day incubation.

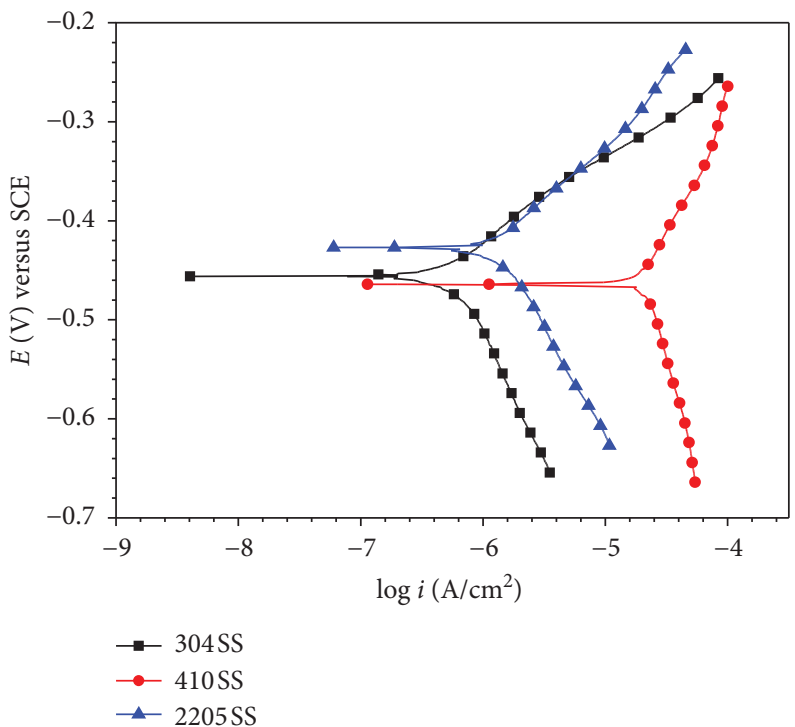

Figure 8: Potentiodynamic polarization curves of 3 stainless steel types after 7-day incubation.

TABLE 6: Tafel parameters fitted from potentiodynamic polarization curves after 7 days.

\begin{tabular}{lcccc}
\hline Metal & $\beta_{\mathrm{a}}(\mathrm{mV} / \mathrm{dec})$ & $\beta_{\mathrm{c}}(\mathrm{mV} / \mathrm{dec})$ & $E_{\text {corr }}(\mathrm{mV})$ versus SCE & $i_{\text {corr }}\left(\mu \mathrm{A} / \mathrm{cm}^{2}\right)$ \\
\hline 304 SS & $70 \pm 4$ & $-275 \pm 9$ & $-427 \pm 2$ & $0.495 \pm 0.003$ \\
410 SS & $257 \pm 12$ & $-428 \pm 11$ & $-466 \pm 4$ & $21.3 \pm 0.1$ \\
2205 SS & $105 \pm 6$ & $-253 \pm 5$ & $-416 \pm 3$ & $1.38 \pm 0.02$ \\
\hline
\end{tabular}

in Table 6. It shows that the $i_{\text {corr }}$ of $410 \mathrm{SS}$ is $21.3 \mu \mathrm{A} / \mathrm{cm} 2$, much larger than the $i_{\text {corr }}$ values of 304 SS and 2205 SS. This directly supports the weight loss data in Table 4 .

\section{Conclusion}

In this work, three kinds of stainless steel (304 SS, 410 SS, and 2205 SS) were inoculated with $D$. ferrophilus to evaluate their corrosion behaviors. After 7 days, 304 SS and 2205 SS yielded undetectable weight loss, while 410 SS had a rather large weight loss of $6.2 \mathrm{mg} / \mathrm{cm}^{2}$. The higher sessile cell count for 410 SS contributed to its large weight loss, but the metallurgical properties likely played a much bigger role. 410 SS contains much less $\mathrm{Cr}$ and $\mathrm{Ni}$ than 304 SS and 2205 SS. Moreover, there was severe pitting on 410 SS (maximum pit depth $118 \mu \mathrm{m}$ ), while well-defined pits were not found on 304 SS and 2205 SS. Electrochemical tests indicated that, at the beginning of the 7-day incubation, 410 SS showed a 
higher corrosion resistance than 304 SS and 2205 SS, suggesting that 410 SS had a better anticorrosion property before the SRB biofilm was fully established. As time went on, 410 SS showed a lower corrosion resistance than 304 SS and 2205 SS. Corrosion current density $\left(i_{\text {corr }}\right)$ data at the end of the 7-day incubation indicated that the $i_{\text {corr }}$ of 410 SS was $21.3 \mu \mathrm{A} / \mathrm{cm}^{2}, 43$ times that for $304 \mathrm{SS}\left(0.495 \mu \mathrm{A} / \mathrm{cm}^{2}\right)$ and 15 times that for $2205 \mathrm{SS}\left(1.38 \mu \mathrm{A} / \mathrm{cm}^{2}\right)$. This directly supports the weight loss data and pitting data.

\section{Data Availability}

The data used to support the findings of this study are available from the corresponding author upon request.

\section{Conflicts of Interest}

The authors declare that there are no conflicts of interest.

\section{Acknowledgments}

This work received financial support from Saudi Aramco and PTTEP of Thailand. JW thanks the China Scholarship Council for studying in the USA. JW and HL acknowledge support by the National Key Research and Development Program of China (2018YFF0215002), Key Laboratory of Materials Chemistry for Energy Conversion and Storage of Ministry of Education (2018), and the Foundation of Hubei Key Laboratory of Materials Chemistry and Service Failure (2017).

\section{References}

[1] H. Sun, X. Wu, E.-H. Han, and Y. Wei, "Effects of pH and dissolved oxygen on electrochemical behavior and oxide films of 304SS in borated and lithiated high temperature water," Corrosion Science, vol. 59, pp. 334-342, 2012.

[2] M. Saadawy, "Kinetics of pitting dissolution of austenitic stainless steel 304 in sodium chloride solution," ISRN Corrosion, vol. 2012, Article ID 916367, 5 pages, 2012.

[3] P. D. Krell, S. Li, and H. Cong, "Synergistic effect of temperature and $\mathrm{HCl}$ concentration on the degradation of AISI 410 stainless steel," Corrosion Science, vol. 122, pp. 41-52, 2017.

[4] Y. Zhao, C. Dong, Z. Jia et al., "Microstructure characteristics and corrosion resistance of friction stir welded 2205 duplex stainless steel," Advances in Materials Science and Engineering, vol. 2021, Article ID 8890274, 11 pages, 2021.

[5] S. Wang, Q. Ma, and Y. Li, "Characterization of microstructure, mechanical properties and corrosion resistance of dissimilar welded joint between 2205 duplex stainless steel and 16MnR," Materials and Design, vol. 32, no. 2, pp. 831-837, 2011.

[6] J. A. Platt, A. Guzman, A. Zuccari et al., "Corrosion behavior of 2205 duplex stainless steel," American Journal of Orthodontics and Dentofacial Orthopedics, vol. 112, no. 1, pp. 69-79, 1997.

[7] L. Bertolini and P. Pedeferri, "Laboratory and field experience on the use of stainless steel to improve durability of reinforced concrete," Corrosion Reviews, vol. 20, no. 1-2, pp. 129-152, 2002 .
[8] L. N. Qiu, Y. N. Mao, A. J. Gong, L. Tong, and Y. Q. Cao, "Inhibition effect of thiobacillus denitrificans on the corrosion of X70 pipeline steel caused by sulfate-reducing bacteria in crude petroleum," Materials and Corrosion, vol. 66, no. 6, pp. 588-593, 2015.

[9] Q. Qu, Y. He, L. Wang et al., "Corrosion behavior of cold rolled steel in artificial seawater in the presence of Bacillus subtilis C2," Corrosion Science, vol. 91, pp. 321-329, 2015.

[10] E. Heitz, W. Sand, and H. Flemming, "Biofouling and microbiologically influenced corrosion (MIC) -an economical and technical overview," Microbial Deterioration of Materials, Springer, vol. 44, , pp. 5-14, 1996.

[11] J. Wang, B. Hou, J. Xiang, X. Chen, T. Gu, and H. Liu, “The performance and mechanism of bifunctional biocide sodium pyrithione against sulfate reducing bacteria in X80 carbon steel corrosion," Corrosion Science, vol. 150, pp. 296-308, 2019.

[12] M. Lv, M. Du, X. Li, Y. Yue, and X. Chen, "Mechanism of microbiologically influenced corrosion of X65 steel in seawater containing sulfate-reducing bacteria and iron-oxidizing bacteria," Journal of Materials Research and Technology, vol. 8, no. 5, pp. 4066-4078, 2019.

[13] J. Wang, F. Xiong, H. Liu et al., "Study of the corrosion behavior of Aspergillus Niger on 7075-T6 aluminum alloy in a high salinity environment," Bioelectrochemistry, vol. 129, pp. 10-17, 2019.

[14] D. Enning, H. Venzlaff, J. Garrelfs et al., "Marine sulfatereducing bacteria cause serious corrosion of iron under electroconductive biogenic mineral crust," Environmental Microbiology, vol. 14, no. 7, pp. 1772-1787, 2012.

[15] S. Y. Li, Y. G. Kim, K. S. Jeon, and Y. T. Kho, "Microbiologically influenced corrosion of underground pipelines under the disbonded coatings," Metals and Materials, vol. 6, no. 3, pp. 281-286, 2000.

[16] A. Abdullah, N. Yahaya, N. Md Noor, and R. Mohd Rasol, "Microbial corrosion of API 5L X-70 carbon steel by ATCC 7757 and consortium of sulfate-reducing bacteria," Journal of Chemistry, vol. 2014, Article ID 130345, 7 pages, 2014.

[17] P. J. Antony, R. K. Singh Raman, R. Mohanram, P. Kumar, and R. Raman, "Influence of thermal aging on sulfate-reducing bacteria (SRB)-influenced corrosion behaviour of 2205 duplex stainless steel," Corrosion Science, vol. 50, no. 7, pp. 1858-1864, 2008.

[18] Z.-H. Liu, A. M. Maszenan, Y. Liu, and W. J. Ng, “A brief review on possible approaches towards controlling sulfatereducing bacteria (SRB) in wastewater treatment systems," Desalination and Water Treatment, vol. 53, no. 10, pp. 2799-2807, 2015.

[19] T. Wu, M. Yan, D. Zeng et al., "Hydrogen permeation of X80 steel with superficial stress in the presence of sulfate-reducing bacteria," Corrosion Science, vol. 91, pp. 86-94, 2015.

[20] T. Wu, M. Yan, D. Zeng et al., "Stress corrosion cracking of X80 steel in the presence of sulfate-reducing bacteria," Journal of Materials Science and Technology, vol. 31, no. 4, pp. 413422, 2015

[21] T. Gu, R. Jia, T. Unsal, and D. Xu, "Toward a better understanding of microbiologically influenced corrosion caused by sulfate reducing bacteria," Journal of Materials Science and Technology, vol. 35, no. 4, pp. 631-636, 2019.

[22] R. Jia, J. L. Tan, P. Jin, D. J. Blackwood, D. Xu, and T. Gu, "Effects of biogenic $\mathrm{H}_{2} \mathrm{~S}$ on the microbiologically influenced corrosion of C1018 carbon steel by sulfate reducing Desulfovibrio vulgaris biofilm," Corrosion Science, vol. 130, pp. 111, 2018. 
[23] H. T. Dinh, J. Kuever, M. Mußmann, A. W. Hassel, M. Stratmann, and F. Widdel, "Iron corrosion by novel anaerobic microorganisms," Nature, vol. 427, no. 6977, pp. 829-832, 2004.

[24] D. Wang, J. Liu, R. Jia et al., "Distinguishing two different Microbiologically Influenced Corrosion (MIC) mechanisms using an electron mediator and hydrogen evolution detection," Corrosion Science, vol. 177, Article ID 108993, 2020.

[25] GASTM G 1-03, Standard Practice for Preparing, Cleaning, and Evaluating Corrosion Test Specimens, American Society for Testing and Materials, Philadelphia, PA, USA, 2003.

[26] U. Eduok, E. Ohaeri, and J. Szpunar, "Accelerated corrosion of pipeline steel in the presence of Desulfovibrio desulfuricans biofilm due to carbon source deprivation in $\mathrm{CO}_{2}$ saturated medium," Materials Science and Engineering: C, vol. 105, Article ID 110095, 2019.

[27] L. Y. Cui, Z. Y. Liu, D. K. Xu et al., "The study of microbiologically influenced corrosion of 2205 duplex stainless steel based on high-resolution characterization," Corrosion Science, vol. 174, Article ID 108842, 2020.

[28] Z. H. Dong, W. Shi, G. A. Zhang, and X. P. Guo, "The role of inhibitors on the repassivation of pitting corrosion of carbon steel in synthetic carbonated concrete pore solution," Electrochimica Acta, vol. 56, no. 17, pp. 5890-5897, 2011.

[29] M. J. Hernández Gayosso, G. Zavala Olivares, N. Ruiz Ordaz et al., "Microbial consortium influence upon steel corrosion rate, using polarisation resistance and electrochemical noise techniques," Electrochima Acta, vol. 49, pp. 4295-4301, 2004.

[30] H. Z. Wadood, A. Rajasekar, A. Farooq, Y.-P. Ting, and A. N. Sabri, "Biocorrosion inhibition of Cu70:Ni30 by Bacillus subtilis strain S1X and Pseudomonas aeruginosa strain ZK biofilms," Journal of Basic Microbiology, vol. 60, pp. 243-252, 2020.

[31] Z. H. Dong, Y. L. Wei, W. Shi, and G. A. Zhang, "Characterisation of doped polypyrrole/manganese oxide nanocomposite for supercapacitor electrodes," Materials Chemistry and Physics, vol. 131, pp. 529-534, 2011.

[32] R. Jia, D. Yang, W. Dou et al., "A sea anemone-inspired small synthetic peptide at sub-ppm concentrations enhanced biofilm mitigation," International Biodeterioration and Biodegradation, vol. 139, pp. 78-85, 2019.

[33] W. Lee and W. G. Characklis, "Corrosion of mild steel under anaerobic biofilm,” Corrosion, vol. 49, pp. 186-199, 1993.

[34] H. Ma, X. Cheng, G. Li et al., "The influence of hydrogen sulfide on corrosion of iron under different conditions," Corrosion Science, vol. 42, pp. 1669-1683, 2000.

[35] J. Xu, R. Jia, D. Yang, C. Sun, and T. Gu, "Effects of d-Phenylalanine as a biocide enhancer of THPS against the microbiologically influenced corrosion of C1018 carbon steel," Journal of Materials Science and Technology, vol. 35, pp. 109-117, 2019. 